\title{
Using Technology-Mediated Board Game on Young Learners
}

\author{
Niluh Putu Puri Palupi Sukenasa ${ }^{1}$, Ju-Ling Shih ${ }^{2}$, Herman Dwi Surjono ${ }^{3}$ \\ Universitas Negeri Yogyakarta, Indonesia ${ }^{1,3}$ \\ National Central University, Taiwan (R.O.C) ${ }^{2}$ \\ Email Correspondence: puripalupi@gmail.com
}

\section{Background:}

Abstract

The use of games and technology for educational purposes can be an appropriate method of enhancing learning performance. Therefore, this study presents a technology-mediated board game and its related course to engage young learners in Indonesia for learning English vocabulary. The study investigated young learners' vocabulary learning performance and learning motivation as the effects of using technology-mediated board game in the course.

\section{Methodology:}

This study employed a quasi-experimental design involving 67 students of one urban and one rural primary school. The vocabularies of fruits and vegetables were implemented online in the game by using QR codes. The instructional practices are to improve students' learning achievement and to find out students' learning motivation. The pre-test, post-test, and Keller's ARCS motivation model were conducted to analyze the effectiveness of technology-mediated board game for learning English vocabulary.

Findings:

The main finding indicated that technology-mediated board games could improve students' English vocabulary learning achievement. Moreover, the use of technology-mediated board games encouraged young learners to have strong learning motivation. On the other hand, the game could promote students to have a concept in gardening that can be encounter in their daily life.

\section{Conclusion:}

These findings imply that technology-mediated board game becomes an effective way of teaching English vocabulary to young learners in Indonesia.

Keywords: Technology-mediated; board game; learning achievement; English vocabulary; situated learning.

\section{DOI $\quad$ : http//dx.doi.org/10.24903/sj.v5i2.507}

\begin{tabular}{|c|c|c|}
\hline Received & : & August 2020 \\
\hline Accepted & : & September 2020 \\
\hline Published & : & October 2020 \\
\hline Copyright Notice & : & $\begin{array}{l}\text { Authors retain copyright and grant the journal right of first publication with the } \\
\text { work simultaneously licensed under a Creative Commons Attribution } 4.0 \\
\text { International License that allows others to share the work with an acknowledgment of } \\
\text { the work's authorship and initial publication in this journal. } \\
\text { (c) (i) (O) }\end{array}$ \\
\hline
\end{tabular}

\section{INTRODUCTION}

The use of technology and games for educational purposes can be an effective way to achieve better learning outcomes. Implementing technology in education provides meaningful learning and engages learners in the learning process (Nikbakht \& Boshrabadi, 2015). Meanwhile, the use of games in learning activities can improve learning performance, enhance 
learning motivation and increase learning interest (Garris, Ahlers, \& Driskell, 2002; Wang, Shang, \& Briody, 2011). As students actively engage in the learning activities, motivation lead an important role that has an impact on students' learning performance (Liao \& Wang, 2008). Therefore, educational games can be used effectively to accomplish learning goals (Shi \& Shih, 2015). Boardgame, as one of the educational games, can engage young learners in the learning process that can affect the learning outcomes. Learning with board game provides an enjoyable, playful, motivational way and encourage learners to interact and compete with others (Noda, Shirotsuki, \& Nakao, 2019). Besides, a board game can engage learners to remain seated, participate during the game and adhere to the rules of the game (Nakao, 2019).

Combining technology into board games may be suitable to assist young learners in learning English vocabulary in which it is essential for young learners' language development. Learning vocabulary helps learners to develop their ability in communication so that they can express their ideas with the knowledge of vocabulary they learned (Hwang \& Wang, 2016). However, learning vocabulary is often considered boring because learners have to remember a lot of vocabulary words and spelling words (Yip \& Kwan, 2006). Therefore, teaching English vocabulary for young learners needs appropriate methods and strategies to improve their performance so that better learning outcomes can be achieved.

To encourage young learners to improve their performance, learning with the game can be a suitable teaching method when it is combined with technology. Games which is used to deliver the learning content known as game-based learning (Tan, Ling, \& Ting, 2007). Meanwhile, learning with the game by using online or on a computer called digital game-based learning (DGBL) (Prensky, 2007). Digital game-based learning holds the learner-centered that makes learning easier, enjoyable, and interesting (Papastergiou, 2009). Moreover, the implementation of digital game-based learning can provide better learning outcomes than the traditional teaching method when the instructional material is integrated into the games (Shih, Chuang, Tseng, \& Shih, 2010). Furthermore, digital game-based learning promotes learning motivation, learning attitudes, and learning effectiveness (Lin \& Shih, 2015).

Providing an interesting environment for young learners can encourage them to understand and remember the new vocabulary words (Huang, Yang, Chiang, \& Su, 2016). The situated learning which is embedded with the activities and scenario into the game can promote learners to improve their comprehension of vocabulary words. The activities such as role-playing help learners to memorize the vocabulary words. The use of role-playing can immerse learners in the learning process, encourage their motivation, and build their new skills or language in which their creativity, skill, and the way of their thinking skills are expected to be promoted 
(Saptono, Soetjipto, Wahjoedi, \& Wahyono, 2020). The most study also found that role-play activities were an effective strategy to enhance vocabulary learning achievement (Alabsi, 2016; Sadeghi \& Sharifi, 2013)

Moreover, the use of situated learning as the game scenario can also immerse learners in the learning process. The purposes of situated learning are to place learners in a real-world context to construct their knowledge and improve their skills through social interaction (Nikbakht \& Boshrabadi, 2015). Learning language through a real-life context can connect learners' prior knowledge with the knowledge gained in the school that can be applied in a reallife environment (Hwang \& Wang, 2016). Some researchers found that the implementation of situated learning in the game could improve learning behaviors, learning performance (Hwang $\&$ Wang, 2016), and learning achievement that makes students become active learning (Cheng, Wang, \& Lin, 2018). Moreover, the use of real-life learning context in the game allows learners not only to learn vocabulary words but also other related subjects. This might be appropriate to support the thematic-integrated learning that is being employed in Indonesia.

Based on the above mentioned, the combination of technology, game, and the learning contents into aboard for an educational purpose called the technology-mediated board game can be an effective and innovative teaching method. In recent years, the integration of technologies into board games has been applied in many different subjects. Previous studies found that integrating technology into board game was effective for improving learning performance (Huang, Lin, Wang, \& Hou, 2019; Wu, Chen, Wang, \& Hou, 2018), learning motivation (Yeh, Hung, \& Hsu, 2017) and promoting collaboration skills (Wang, Chen, Hou, $\& \mathrm{Li}, 2017)$ compared with the traditional teaching method. Unfortunately, integrating technology into the board game in the field of language learning has not been widely adopted. Thus, in this study, the technology-mediated board game was developed by integrating quick response (QR) codes into board games in learning English vocabulary.

Technology-mediated board game can contribute new ideas for educators in creating fun and engaging learning environment by utilizing technology and games to increase learners' performance and motivation in learning vocabulary. Garden Island board game as a technology-mediated board game was designed to help young learners acquire the vocabulary words in fun, playful and enjoyable learning. Besides, the Garden Island board game was developed not only for learning vocabulary but also the gardening concept to support the thematic-integrated learning process in Indonesia. Therefore, this study investigated the effect of using the Garden Island board game to improve young learners' vocabulary learning achievement and to find out their learning motivation through the educational game. 


\section{METHODOLOGY}

This research is an educational study employed a quasi-experimental method with pretestposttest nonequivalent-group design to know the effectiveness of using technology-mediated board games in improving students' English vocabulary achievement in urban and rural primary school. According to Best and Kahn (2006), "this design is often used in classroom experiments when experimental and control group are such naturally assembled group as intact classes which may be similar". This study also analyzed students' motivation towards the use of technology-mediated board games in learning vocabulary. In response to the aims of this study, quantitative analysis was used to collect the data. The total participants were 67 participants of one urban primary school and one rural primary school in a different province of Indonesia, where the utilization of technology for educational purposes has not been widely applied in primary schools. The subjects in the urban primary school of East Java Province consisted of 43 first-grade students, and the rural school of Bali Province consisted of 24 first-grade students.

The data collected in this study was used pre-test, post-test, and Keller's ARCS questionnaire. The pre-test and post-test used in this study are to measure students' vocabulary achievement about fruits and vegetables. The pre-test and post-test have the same difficulty level. The test consists of 25 items in four different parts. The first part consists of 10 items multiple-choice of the listening test, and the second part consists of 5 items of differentiating vowels, the third part consists of 5 items matching a word with a picture and the last part consists of 5 items of spelling word. The data were analyzed by using paired sample t-test, ANCOVA, independent sample t-test in SPSS. The result was used to support the quantitative analysis of students' learning achievement. Meanwhile, Keller's ARCS motivation (Attention, Relevance, Confidence, Satisfaction dimension) questionnaire was used to investigate the degree of students' motivation. There were 16 questions used four Likert scales; strongly disagree (1), disagree (2), agree (3), and strongly agree (4). The overall reliability of standardized Cronbach Alpha was .644 ( $n=67$ on 16 questions), which suggested a significantly reliable. The data of students' motivation questionnaires were analyzed by using the descriptive statistic in SPSS.

The treatment in this study was conducted in three hours (180 minutes) of one-day treatment. Some teaching staff and Garden Island board game were used to guide students in learning vocabulary (Figure 1). The Garden Island board game played by four to eight students in which each island could be played in pairs. Garden Island board game used in this study described as follows: 
Garden Island was designed for grade I students who are 7 to 8 years old. In playing the game, students take the role of a gardener. They had to collect the three cards of a seed plant, fertilizer, and water card in sequence to fill each of the brown boxes (Figure 2). In collecting the cards, students had to answer the questions by scanning the QR codes at the back of the cards by using the mobile phone provided which was linked to the Garden Island board game website developed by the researcher (Figure 3). On the website, there were three kinds level of questions (listening words, differentiating vowels, missing vowels) with a total of 60 different questions (Figure 4). Students could get the cards and have one chance to use the card if they choose the right answer. On the other hand, students could not get the cards and lose their chance to play if they choose the wrong answer. After collecting the last cards or the water card, students could get an opportunity to change all three cards into one of fruit or vegetable cards as the rewards of the game. Students who fill the three brown boxes with fruits or vegetable cards could be the winner of the game.

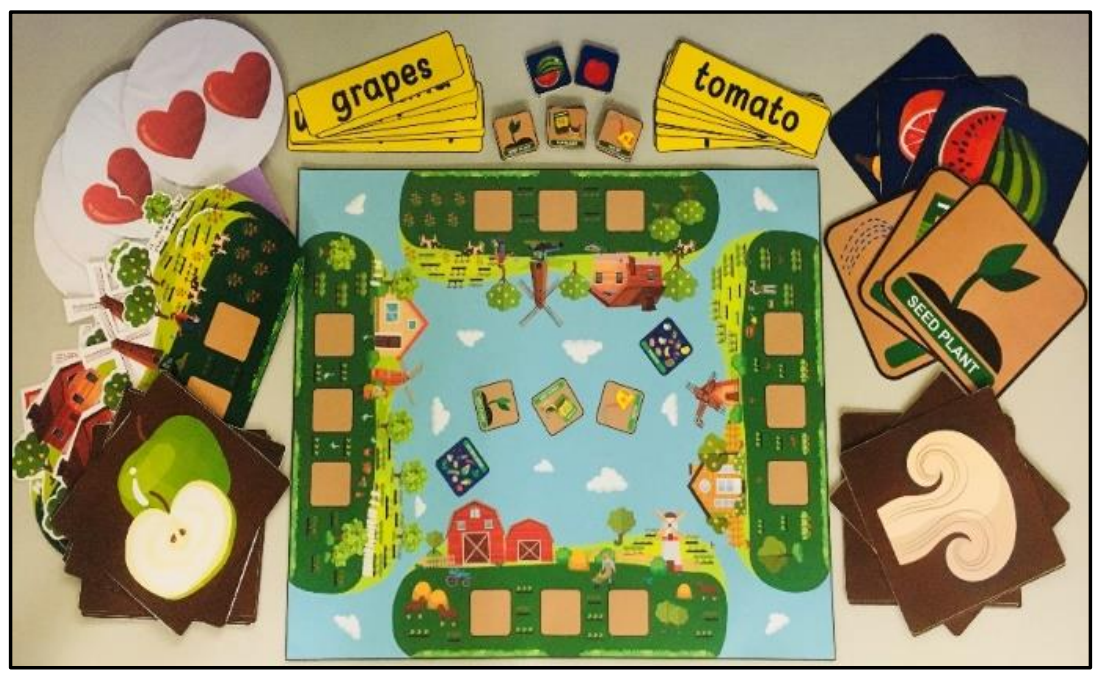

Figure 1. Teaching Stuffs and Garden Island Board Game

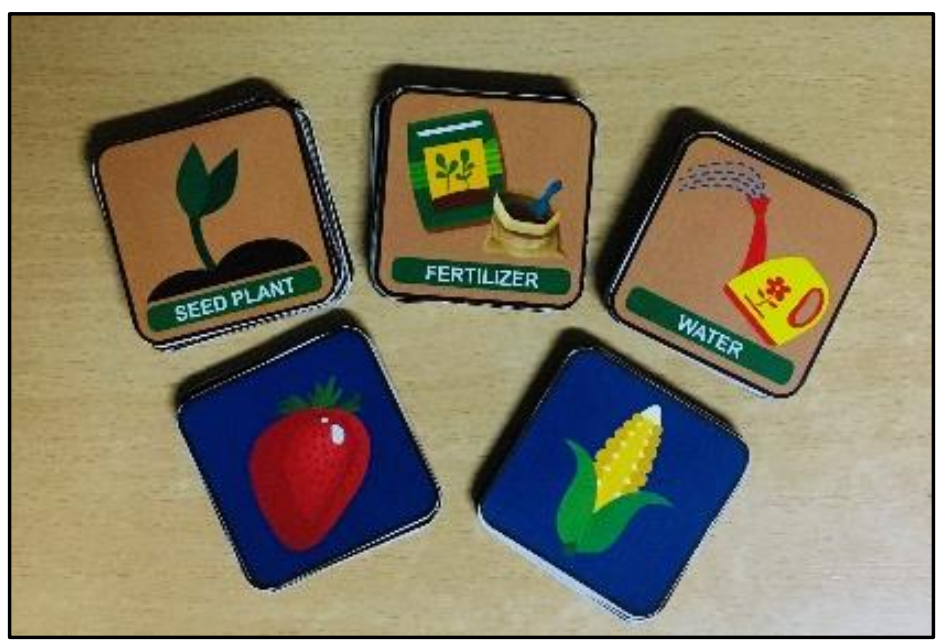

Figure 2. The Cards 


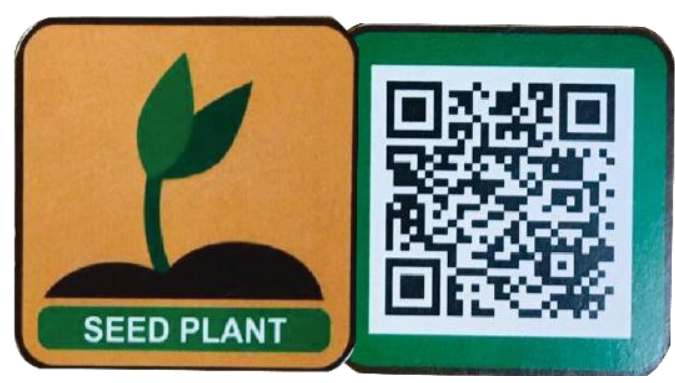

Figure 31. Example of Front and Back Cards

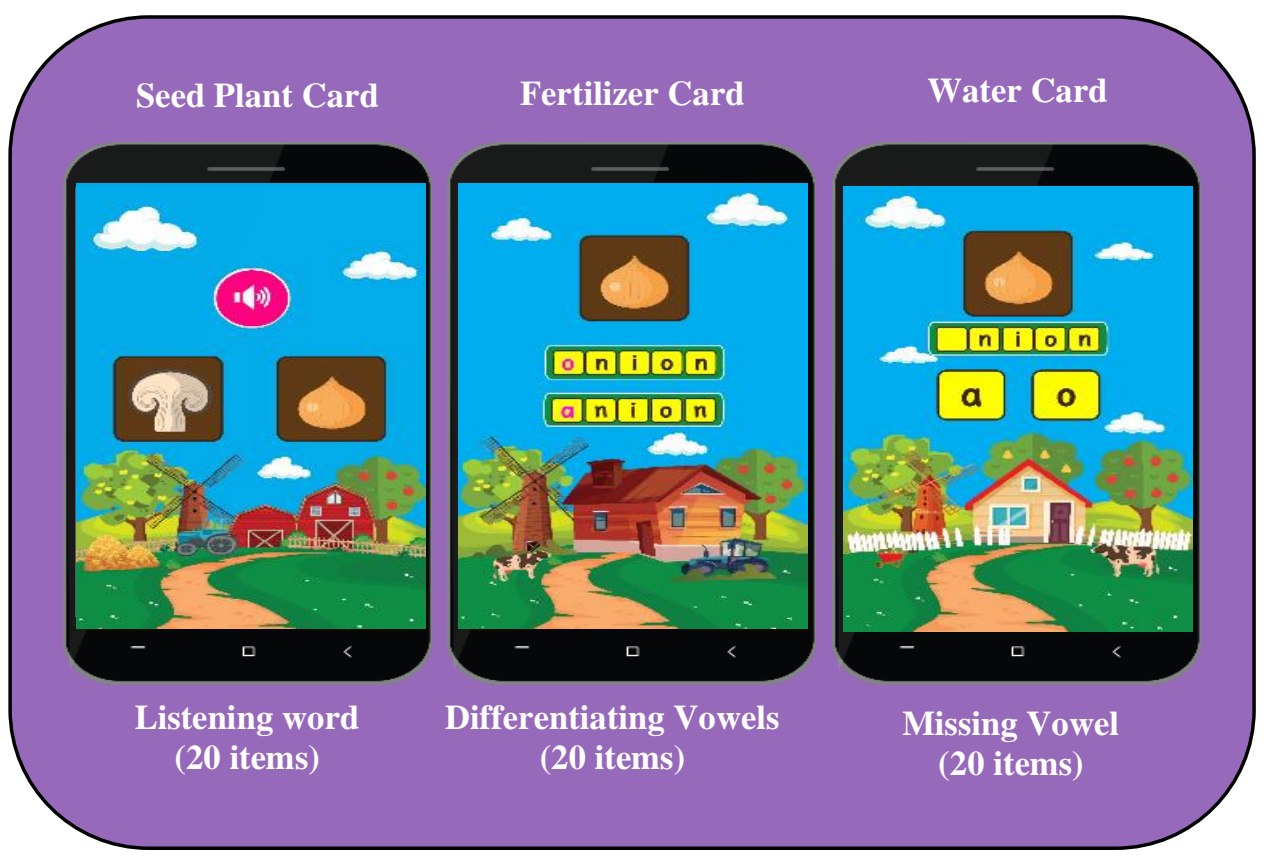

Figure 42. Questions Levels in Garden Island Website for Each Card

\section{FINDINGS}

\subsection{Vocabulary Learning Achievement}

Based on Table 1, the result of paired sample t-test between pre-test $(\mathrm{M}=55.07)$ and posttest $(\mathrm{M}=76.84)$ of grade I students in urban school showed that there was significance difference $(t=14.61, p<.000)$. Furthermore, the average scores between pre-test $(M=41.67)$ and post-test $(\mathrm{M}=71.33)$ of grade I students in rural school showed that there was significant difference $(t=12.58, p<.004)$.

Table 1. Paired Sample T-test of Pre-test and Post-test of Grade I in Urban and Rural Primary School

\begin{tabular}{cccccccc}
\hline & & Mean & N & SD & Mean Difference & $t$ & Sig. \\
\hline Urban School & Pretest & 55.07 & 43 & 15.88 & 21.77 & $14.61^{*}$ & .000 \\
& Posttest & 76.84 & 43 & 11.99 & & & \\
Rural School & Pretest & 41.67 & 24 & 12.25 & 29.67 & $12.58^{*}$ & .004 \\
& Posttest & 71.33 & 24 & 12.41 & & & \\
\hline
\end{tabular}

The results of both urban school and rural schools showed that students' learning achievement in learning English vocabulary with the Garden Island board game has improved. 
The overall result determined that the effect of using the Garden Island board game was beneficial for students to have a better understanding of fruits and vegetable vocabulary.

However, the average scores of each part in the test between urban school and rural school was almost different. The independent sample t-test was used to determine the difference scores between pre-test in an urban school and a rural school, and between post-test in an urban school and the rural school. In Table 2, the pre-test scores in part 1 between urban school and rural school were significantly different $(t=2.43, p<.018)$. In contrast, there was no significant difference $(t=-1.42, p>.161)$ in Part 2 between urban school and rural school which meant both students in those schools had similar ability in differentiating vowels. In Part 3, there was significantly different $(t=3.55, p<.001)$ between urban school and rural school. Furthermore, there was also a significantly different $(t=3.59, p<.001)$ between an urban school and a rural school in part 4. It concluded that the result of the pre-test between grade I students in an urban school $(\mathrm{M}=55.07, \mathrm{SD}=15.88)$ and in rural school $(\mathrm{M}=41.67, \mathrm{SD}=12.25)$ showed that there were significantly different $(t=3.58, p<.001)$ which means grade I students of the urban school and the rural school had different prior knowledge about English vocabulary related fruits and vegetables.

Table 2. Independent Sample T-test of Pre-test between Grade I in Urban and Rural Primary School

\begin{tabular}{|c|c|c|c|c|c|c|c|}
\hline & Group & Mean & $\mathrm{N}$ & SD & Mean Difference & $t$ & Sig. (2-tailed) \\
\hline Part 1 & Urban School & 28.09 & 43 & 6.38 & \multirow[t]{2}{*}{4.43} & \multirow[t]{2}{*}{$2.43^{*}$} & \multirow[t]{2}{*}{.018} \\
\hline (Listening) & Rural School & 23.67 & 24 & 8.33 & & & \\
\hline Part 2 & Urban School & 7.35 & 43 & 4.61 & \multirow[t]{2}{*}{-1.82} & \multirow[t]{2}{*}{-1.42} & \multirow[t]{2}{*}{.161} \\
\hline (Vowels) & Rural School & 9.17 & 24 & 5.71 & & & \\
\hline Part 3 & Urban School & 10.23 & 43 & 7.05 & \multirow[t]{2}{*}{5.57} & \multirow[t]{2}{*}{$3.55^{*}$} & \multirow[t]{2}{*}{.001} \\
\hline (Pictures-Word) & Rural School & 4.67 & 24 & 4.03 & & & \\
\hline Part 4 & Urban School & 9.40 & 43 & 5.91 & \multirow[t]{2}{*}{5.23} & \multirow[t]{2}{*}{$3.59^{*}$} & \multirow[t]{2}{*}{.001} \\
\hline (Spelling) & Rural School & 4.17 & 24 & 5.34 & & & \\
\hline Total & Urban School & 55.07 & 43 & 15.88 & \multirow[t]{2}{*}{13.40} & \multirow[t]{2}{*}{$3.58^{*}$} & \multirow[t]{2}{*}{.001} \\
\hline & Rural School & 41.67 & 24 & 12.25 & & & \\
\hline
\end{tabular}
"p<.05

Based on the results above, the ANCOVA analysis was conducted due to the pre-test between urban school and rural school showed that there was a significantly different. The ANCOVA analysis was used to control experimental manipulation in the pre-test. As displayed in Table 3, the group pre-test between urban and rural schools showed that there was no significant difference in the homogeneity of regression $(F=0.026, p>.873)$ which meant students had the same prior knowledge.

Table 3. ANCOVA Result of Pre-test between Grade 1 in Urban \& Rural Primary School

\begin{tabular}{lccccc}
\hline \multicolumn{1}{c}{ Source } & Type III Sum of Squares & df & Mean Square & $F$ & Sig. \\
\hline Corrected Model & $5337.605^{\mathrm{a}}$ & 3 & 1.779 .202 & 23.828 & .000 \\
Intercept & 9.843 .029 & 1 & 9.843 .029 & 131.821 & .000 \\
Group & 15.299 & 1 & 15.299 & 0.205 & .652 \\
Pre-test & 3.527 .708 & 1 & 3.527 .708 & 47.244 & .000 \\
\hline
\end{tabular}




\begin{tabular}{|c|c|c|c|c|c|}
\hline Group * Pre-test & 1.935 & 1 & 1.935 & $0.026^{*}$ & .873 \\
\hline Error & 4.704 .186 & 63 & 74.670 & & \\
\hline Total & 385.568 .000 & 67 & & & \\
\hline Corrected Total & 10.041 .791 & 66 & & & \\
\hline \multicolumn{6}{|c|}{ a. R Squared $=, 532($ Adjusted R Squared $=, 509)$} \\
\hline
\end{tabular}

Moreover, the analysis of covariance (ANCOVA) was performed to explore the learning difference in the post-test scores of grade I students. The result in Table 4 showed that the adjusted mean of urban school was 74.01, while the adjusted mean of rural schools was 76.40 . This indicated that there was no significant difference between the post-test of grade I students in the urban and rural schools $(F=1.00, p<.321)$.

Table 41. ANCOVA Result of Post-test between Grade I in Urban \& Rural Primary School

\begin{tabular}{cccccc}
\hline Group & $\mathrm{N}$ & Adjusted Mean & Std error & $F$-value & Sig. \\
\hline Urban School & 43 & 74.01 & 1.35 & \multirow{2}{*}{$1.00^{*}$} & .321 \\
Rural School & 24 & 76.40 & 1.86 & & \\
\hline${ }^{*} p<.05$ & & & & &
\end{tabular}

The independent sample t-test was also conducted to examine the average difference scores between the post-test of grade I students in an urban school and rural school. The post-test result of part 1 in Table 5 showed that there was no significant difference $(t=-1.13, p>.263)$ between urban school and rural school which means students had equal ability in listening skills. In part 2, the result of the post-test showed that there was a significantly different $(t=$ $3.08, p<.003)$ which means students in the urban school had a better understanding of differentiating vowels than students in a rural school. Furthermore, in part 3, the result showed that there was no significant difference $(t=-0.57, p>.567)$ between urban school and rural school. It indicated that students of the rural school had a similar ability with grade I students of an urban school in matching the picture with the correct word test. Moreover, the result in part 4 showed that there was a significantly different $(t=2.47, p<.016)$ between urban school and rural school. Although there was a significantly different in part 4, those two schools had low average scores which meant that grade I students in an urban school and rural school still had difficulty in spelling words.

Therefore, the average result of grade I post-test in all parts showed that there was no significant difference $(t=1.78, p=.080)$ between urban school and rural school. The average result of all parts in urban school $(\mathrm{M}=77.84, \mathrm{SD}=11.99)$ and rural school $(\mathrm{M}=71.33, \mathrm{SD}=$ 12.41) were quite similar. Based on the result, it showed that grade I students in the urban school had a bigger improvement than grade I students in a rural school. However, the posttest results concluded that the Garden Island board game has a great impact on students' vocabulary learning achievement in an urban and rural school. 
Table 52. Independent Sample T-test of Post-test between Grade I in Urban and Rural Primary School

\begin{tabular}{|c|c|c|c|c|c|c|c|}
\hline & Group & Mean & $\mathrm{N}$ & $\mathrm{SD}$ & Mean Difference & $t$ & Sig. (2-tailed) \\
\hline Part 1 & Urban School & 33.58 & 43 & 5.32 & \multirow[t]{2}{*}{-1.42} & -1.13 & \multirow[t]{2}{*}{.263} \\
\hline (Listening) & Rural School & 35.00 & 24 & 4.13 & & & \\
\hline Part 2 & Urban School & 12.74 & 43 & 4.80 & \multirow[t]{2}{*}{4.08} & $3.08^{*}$ & \multirow[t]{2}{*}{.003} \\
\hline (Vowels) & Rural School & 8.67 & 24 & 5.86 & & & \\
\hline Part 3 & Urban School & 16.74 & 43 & 5.67 & \multirow[t]{2}{*}{-0.76} & -0.57 & \multirow[t]{2}{*}{.567} \\
\hline (Pictures-Word) & Rural School & 17.50 & 24 & 4.05 & & & \\
\hline Part 4 & Urban School & 13.77 & 43 & 5.11 & \multirow[t]{2}{*}{3.60} & $2.47^{*}$ & \multirow[t]{2}{*}{.016} \\
\hline (Spelling) & Rural School & 10.17 & 24 & 6.67 & & & \\
\hline Total & Urban School & 76.84 & 43 & 11.99 & \multirow[t]{2}{*}{5.50} & 1.78 & \multirow[t]{2}{*}{.080} \\
\hline & Rural School & 71.33 & 24 & 12.41 & & & \\
\hline
\end{tabular}

\subsection{Students Motivation}

As displayed in Table 6, the result of ARCS questionnaire showed positive feedback on students' learning motivation, both urban school and rural school that almost reached 4 points in all aspects. Attention dimension scored 3.87 and 3.70; Relevance scored 3.75 and 3.53; Confidence scored 3.59 and 3.22; and Satisfaction scored 3.90 and 3.63. The result of the ARCS motivation of 67 students showed that the average motivation was 3.73 of urban school and 3.52 of the rural school. These indicated that most students in both schools were satisfied with the use of the Garden Island board game in learning English vocabulary.

Table 6. Descriptive Statistic of ARCS Motivation Questionnaire

\begin{tabular}{ccccc}
\hline \multirow{2}{*}{ Dimension } & \multicolumn{2}{c}{ Urban School } & \multicolumn{2}{c}{ Rural School } \\
\cline { 2 - 5 } & Mean & SD & Mean & SD \\
\hline Attention & 3.87 & 0.35 & 3.70 & 0.54 \\
Relevance & 3.75 & 0.70 & 3.53 & 0.97 \\
Confidence & 3.59 & 0.87 & 3.22 & 0.09 \\
Satisfaction & 3.90 & 0.40 & 3.63 & 0.84 \\
Overall & 3.73 & 0.63 & 3.52 & 0.86 \\
\hline
\end{tabular}

Furthermore, the average scores in each dimension showed three points for each grade (Table 7). Moreover, the result showed that 29 (67\%) of 43 grade I students in an urban school and $17(71 \%)$ of 24 students in the rural school had upper-medium level.

Table 7. Range of Motivation Level between Urban and Rural Primary School

\begin{tabular}{cccccc}
\hline \multirow{2}{*}{ Motivation Level } & \multirow{2}{*}{ Scores } & \multicolumn{2}{c}{ Urban School } & \multicolumn{2}{c}{ Rural School } \\
\cline { 2 - 6 } & & $\mathrm{N}$ & $\%$ & $\mathrm{~N}$ & $\%$ \\
\hline High Level & $4.00-5.00$ & 10 & $23 \%$ & 0 & $0 \%$ \\
Upper-Medium Level & $3.50-3.99$ & 29 & $67 \%$ & 17 & $71 \%$ \\
Medium Level & $3.00-3.49$ & 4 & $9 \%$ & 7 & $29 \%$ \\
Low Level & $<3.00$ & 0 & $0 \%$ & 0 & $0 \%$ \\
Total & & 43 & $100 \%$ & 24 & $100 \%$ \\
\hline
\end{tabular}

\section{DISCUSSION}

The use of technology in a board game is an effective way of learning English vocabulary compared with the traditional teaching method. The major finding of this study indicated that students' vocabulary learning achievement in urban and rural primary schools showed greater improvement. However, the findings of the pre-test and the post-test result showed that students 
get lower average scores in a spelling test. It indicated that most students in urban and rural schools still had difficulty in arranging the words. There should be any spelling activities provided for practicing through the website to develop students' spelling skills. Despite that, the overall result showed that the Garden Island board game could improve students' vocabulary learning performance. This approach then proved that integrating technology into a board game could produce better learning achievement as proposed by Wang et al. (2017) and $\mathrm{Wu}$ et al. (2018)

The situated learning embedded in the game scenario and the activities encourage students to have better vocabulary comprehension. The use of the game scenario in a real-life learning context could immerse learners in a situation that encourages students to have a better understanding and remembering the vocabulary words through social interaction. When students played the game, they construct their knowledge through interaction with their pair. Students worked and discussed together to decide the correct answer to get the cards. The result after the treatment found that the pre-test and post-test scores are significantly increased. The pre-test and post-test scores in urban schools are 55.07 and 76.84, and rural schools are 41.67 and 71.33. The study of Huang et al. (2016), Hwang and Wang (2016), and Cheng et al. (2018) further confirmed this finding that implementing situational context in the game for learning English vocabulary could produce better learning achievement. Besides, the use of role-playing as the activities in the game also helped students to memorize vocabulary words that affect learning achievement. It appeared when students took a role as a gardener, and they started to collect the cards in sequence. While collecting the cards, students had to answer different questions of each card that encourage them to practice in memorizing the vocabulary words. Alabsi (2016) and Sadeghi and Sharifi (2013) also support this finding that role-plays strategies could increase vocabulary learning achievement.

Moreover, the Garden Island board game promotes students to develop knowledge in gardening concepts. Providing with seed plant, fertilizer and water cards in the game make students learn the concept of planting until they can harvest their plant. It indicated that the Garden Island board game enables students to develop knowledge of the gardening concept in which they encountered in their daily lives. Therewith, learning gardening concept while learning vocabulary can support teachers and schools in Indonesia to implement the thematicintegrated learning process, which is still difficult to be employed in daily teaching.

Furthermore, the Garden Island board game encourages students to have a strong motivation in learning vocabulary. The finding of the motivation questioner showed that both students in the urban and rural schools were pretty high. This indicated that the Garden Island 
board game provides a fun and enjoyable learning that can engage students' emotions of curiosity, attention, confidence that make them satisfied in learning vocabulary with the Garden Island board game. This showed that students with high learning motivation have better learning achievement. The finding of the motivation questionnaire consistent with $\mathrm{Wu}(2018)$ that learning motivation enhances competency, which affects greater learning effectiveness.

\section{CONCLUSION}

Integrating technology into the Garden Island board game, which includes the learning content provides a fun, engaging, and immersing way of learning vocabulary that may not be achieved in a traditional classroom. Therefore, the implementation of technology in language learning through the educational game is important to have effective teaching practices in achieving the learning goals. Based on these findings, the use of technology in board games can facilitate primary school students in improving students' vocabulary achievement and engage them to have strong learning motivation. Thus, the technology-mediated board game called Garden Island board game becomes an effective and innovative teaching method that can be implemented in daily teaching of English language learning in Indonesia.

\section{REFERENCES}

Alabsi, T. A. (2016). The Effectiveness of role-play strategy in teaching vocabulary. Theory and Practice in Language Studies, 6, 227-234.

Best, J. W., \& Kahn, J. V. (2006). Research in education. New York: Pearson Education Inc.

Cheng, C.I., Wang, S.W., \& Lin, L.W. (2018). A study on the effect of using digital games for self-learning of English in elementary school. In T.T. Wu, Y.M. Huang, R. Shadiev, L. Lin, \& A. I. Starčič (Eds.), Innovative technologies and learning. ICTL 2018. Lecture Notes in Computer Science (Vol. 11003, pp. 393-402): Springer Cham. doi:10.1007/978-3-319-99737-7_42

Garris, R., Ahlers, R., \& Driskell, J. E. (2002). Games, motivation, and learning: A research and practice model. Simulation \& Gaming, 33(4), 441-467. doi:10.1177/1046878102238607

Huang, C.Y., Lin, H.T., Wang, S.M., \& Hou, H.T. (2019). Designing a gamified activity with visual representaion-based scenario and technology-based scaffoldings for learning electric potential. IEEE International Conference on Consumer Electronics - Taiwan (ICCE-TW), 1-2. doi:10.1109/ICCE-TW46550.2019.8991794

Huang, C. S. J., Yang, S. J. H., Chiang, T. H. C., \& Su, A. Y. S. (2016). Effects of situated mobile learning approach on learning motivation and performance of EFL students. Educational Technology \& Society, 19(1), 263-276.

Hwang, G.J., \& Wang, S.Y. (2016). Single loop or double loop learning: English vocabulary learning performance and behavior of students in situated computer games with different guiding strategies. Computers \& Education, 102, 188-201. doi:10.1016/j.compedu.2016.07.005 
Liao, H.C., \& Wang, Y.h. (2008). Applying the ARCS motivation model in technological and vocational education. Contemporary Issues In Education Research, 1(2).

Lin, C.H., \& Shih, J.L. (2015). Evaluations to the gamification effectiveness of digital gamebased adventure education course - GILT. Journal of e-Learning and Knowledge Society, 11(3), 41-58.

Nakao, M. (2019). Special series on "effects of board games on health education and promotion" board games as a promising tool for health promotion: a review of recent literature. BioPsychoSocial Medicine, 13(5). doi:10.1186/s13030-019-0146-3

Nikbakht, E., \& Boshrabadi, A. M. (2015). Analysing the potential of social networking sites on EFL learners' vocabulary mastery: A situated-learning approach. Theory and Practice in Language Studies, 5(8), 1635-1641. doi:10.17507/tpls.0508.13

Noda, S., Shirotsuki, K., \& Nakao, M. (2019). The effectiveness of intervention with board games: a systematic review. BioPsychoSocial Medicine, 13(22). doi:10.1186/s13030019-0164-1

Papastergiou, M. (2009). Digital game-based learning in high school computer science education: Impact on educational effectiveness and student motivation. Computers \& Education, 52, 1-12. doi:10.1016/j.compedu.2008.06.004

Prensky, M. (2007). Digital game-based learning. United States: Paragon House.

Sadeghi, K., \& Sharifi, F. (2013). The effect of post-teaching activity type on vocabulary learning of elementary EFL learners. English Language Teaching, 6(11). doi:10.5539/elt.v6n11p65

Saptono, L., Soetjipto, B. E., Wahjoedi, \& Wahyono, H. (2020). Role-playing model: Is it effective to improve students' accounting learning motivation and learning achievements? Cakrawala Pendidikan, 39(1), 133-143. doi:10.21831/cp.v39i1.24781

Shi, Y.R., \& Shih, J.L. (2015). Game factors and game-based learning design model. International Journal of Computer Games Technology. doi:10.1155/2015/549684

Shih, J.L., Chuang, C.W., Tseng, J.J., \& Shih, B.J. (2010). Designing a role-play game for learning Taiwan history and geography. The 3rd IEEE International Conference on Digital Game and Intelligent Toy Enhanced Learning (DIGITEL), 54-60. doi:10.1109/DIGITEL.2010.27

Tan, P.H., Ling, S.W., \& Ting, C.Y. (2007). Adaptive Digital Game-Based Learning Framework. Paper presented at the The 2nd International Conference on Digital Interactive Multimedia in Entertainment and Arts.

Wang, S.M., Chen, K.T., Hou, H.T., \& Li, C.T. (2017). A Science History Educational Board Game with Augmented Reality Integrating Collaborative Problem Solving and Scaffolding Strategies. Paper presented at the Workshop Proceedings of the 25th International Conference on Computers in Education, New Zealand.

Wang, Y.J., Shang, H.F., \& Briody, P. (2011). Investigating the Impact of Using Games in Teaching Children English. International Journal of Learning \& Development, 1(1). doi:10.5296/ijld.v1i1.1118

Wu, C.H., Chen, C.C., Wang, S.M., \& Hou, H.T. (2018). The Design and Evaluation of a Gamification Teaching Activity using Board Game and QR Code for Organic Chemical Structure and Functional Groups Learning. 7th International Congress on Advanced Applied Informatics. doi:10.1109/IIAI-AAI.2018.00190

$\mathrm{Wu}, \mathrm{T}$. T. (2018). Improving the effectiveness of English vocabulary review by integrating ARCS with mobile game-based learning. Journal of Computer Assisted Learning, 34, 315-323. doi:10.1111/jcal.12244 
Yeh, Y.T., Hung, H.T., \& Hsu, Y.J. (2017). Digital Game-Based Learning for Improving Students' Academic Achievement, Learning Motivation, and Willingness to Communicate in an English Course. 6th IIAI International Congress on Advanced Applied Informatics. doi:10.1109/IIAI-AAI.2017.40

Yip, F. W. M., \& Kwan, A. C. M. (2006). Online Vocabulary Games as a Tool for Teaching and Learning English Vocabulary. Educational Media International, 43(3), 233-249. doi:10.1080/09523980600641445 